\title{
How to Prevent Fogging of Spectacle Glasses When Wearing a Face Mask
}

\author{
Pawan Agarwal $^{1}$ (D) $\cdot$ D. Sharma ${ }^{2}$
}

Received: 2 November 2020 / Accepted: 7 January 2021 / Published online: 15 January 2021

(C) Association of Surgeons of India 2021

\section{Dear Editor in Chief, Indian Journal of Surgery}

World Health Organization (WHO) has recommended wearing face masks by general public as a preventive measure against Coronavirus Disease 2019 (COVID-19) [1]. However, wearing a mask may cause fogging of spectacle glasses. Lack of airtight fitting between the upper border of mask and face results in exhaled air traveling in an upward direction. Contact between warmer exhaled air and cooler spectacle glasses results in condensation and formation of tiny water droplets which scatter the light, reduce visual acuity, and adversely affect overall vision $[2,3]$. Surgeons have a long experience in dealing with this problem; we share some of our time-tested solutions on this issue of contemporary significance.

These ideas can be classified in to:

1. Improving the barrier between mask and glasses:

- Pinching of wire/metal strip on the upper border of the mask for better fit.

- Taping of upper border of mask to nose and facial skin with a porous adhesive tape or converting the eyewear to a filtered eye mask by creating vents sealed with N95 mask cutting [4].

- Cross-tying of the mask; tying upper tie first and below the year and then tying lower tie on the top of crown. This creates a tighter fit and two lateral

Pawan Agarwal

drpawanagarwal@yahoo.com

1 Plastic Surgery Unit, Department of Surgery NSCB Government, Medical College Jabalpur, 292/293, Napier Town, Jabalpur, Madhya Pradesh 482003, India

2 Department of Surgery, NSCB Government Medical College, Jabalpur, Madhya Pradesh 482003, India 'vents', allowing exhaled air to escape away from the glasses.

- Other ideas include keeping a folded tissue paper under the mask at the bridge of nose to absorb escaping moisture and keeping the glasses slightly away from the face on the nose to allow venting space for exhaled air.

2. Detergent-based surfactant coating of glasses to reduce the fogging: thin coating of surfactant reduces the surface tension between the condensed water molecules; so, instead of coalescing together to fog, they spread into a thin, uniform, and transparent layer on the glass. Diluted liquid hand soap or diluted shampoo or propranolol-based skin disinfectant is applied to the glasses and then wiped off with a soft cotton cloth after $20 \mathrm{~s}$ to leave a thin film $[5,6]$. This is similar to Scuba divers' traditional technique to prevent fogging of eyewear by using spit/diluted liquid soap/ shampoo on inner surface of their goggles. Detergentbased surfactant coating has been shown to work better and longer, in simulated conditions than other ideas [7].

3. Other ideas include use of anti-fog lenses, commercial anti-fogging chemical coating (polyethylene terephthalate, titanium dioxide) films, and use of polycarbonate spectacle lenses which defog faster than glass lenses [2, 8]. A well-ventilated working environment with good air circulation also prevents fogging of lenses. If everything fails, then one may have to switch to contact lenses.

As the COVID pandemic continues to rage across the world, idea of mask wearing by general population is here to stay, at least for foreseeable future. If wearing a mask causes fogging of spectacle glasses, several effective and inexpensive solutions can be borrowed from traditional surgical practices.

Data Availability NA. 


\section{Compliance with Ethical Standards}

Conflict of Interest The authors declare that they have no conflict of interest.

Code Availability NA.

\section{References}

1. WHO: Coronavirus disease (COVID-19) advice for the public. Available from https://www.who.int/emergencies/diseases/novelcoronavirus-2019/advice-for-public?gclid=EAIaIQobChMIzO vM9bbM7AIVgQsrCh1fdg3NEAAYASADEgKJo_D_BwE. Last updated on 13th October 2020. Accessed on 24th October 2020

2. Margrain TH, Owen C (1996) The misting characteristics of spectacle lenses. Ophthalmic Physiol Opt 16(2):108-114

3. Crebolder JM, Sloan RB (2004) Determining the effects of eyewear fogging on visual task performance. Appl Ergon 35(4):371-381. https://doi.org/10.1016/j.apergo.2004.02.005
4. Bhardwaj A, Sharma C, Rajan MB (2020) Simple solutions for fogging of spectacles on wearing surgical masks. J Am Acad Dermatol. https://doi.org/10.1016/j.jaad.2020.08.041

5. Kyle J (ed) (1977) Pye's Surgical Handicraft, 20th edn. John Wright and Sons Ltd., Bristol

6. Pandey K, Vig S, Ratre B, Gupta N (2020) Use of Sterillium on protective goggles for anti-fogging during donning for care of COVID-19 patients: a novel technique. Turk J Anaesthesiol Reanim 48(4):344-345. https://doi.org/10.5152/TJAR.2020.682

7. Kumar A, Qureshi OA, Arora R, Kumar S, Jameel J, Khan R (2020) Comparison of three low-cost techniques to control fogging of sealed eyewear in a simulated operating room environment: a preliminary analysis. J Clin Orthop Trauma 11(Suppl 5):S696-S699. https://doi. org/10.1016/j.jcot.2020.07.009

8. Duran IR, Laroche G (2019) Current trends, challenges, and perspectives of anti-fogging technology: surface and material design, fabrication strategies, and beyond. Prog Mater Sci 99:106e186

Publisher's Note Springer Nature remains neutral with regard to jurisdictional claims in published maps and institutional affiliations. 